
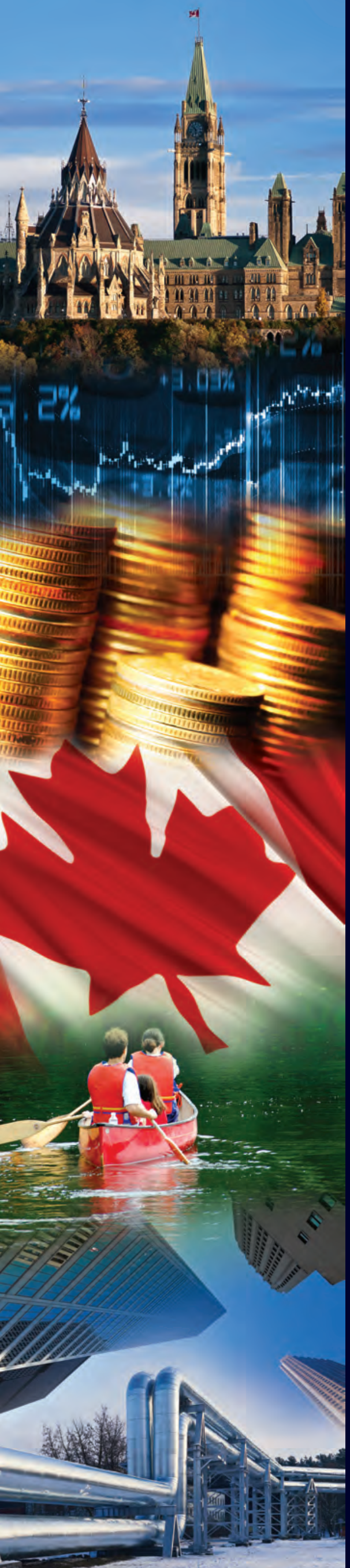

COMMENTARY

NO. 481

\title{
Tax Options for \\ Childcare that Encourage Work, Flexibility, Choice, Fairness and Quality
}

Moving to a new refundable tax credit for childcare would generate the social benefits of increased labour-force participation, benefit lower-income parents, and allow for flexible and decentralized childcare choices.

Alexandre Laurin and Kevin Milligan 


\section{THE C.D. HOWE INSTITUTE'S COMMITMENT TO QUALITY, INDEPENDENCE AND NONPARTISANSHIP}

\section{ABOUT THE AUTHORS}

Alexandre Laurin is Director of Research at the C.D. Howe Institute.

Kevin Milligan is Professor, Vancouver School of Economics, University of British Columbia and a Fellow-in-Residence of the C.D. Howe Institute.
Commentary No. 481

May 2017

Fiscal and Tax Policy
The C.D. Howe Institute's reputation for quality, integrity and nonpartisanship is its chief asset.

Its books, Commentaries and E-Briefs undergo a rigorous two-stage review by internal staff, and by outside academics and independent experts. The Institute publishes only studies that meet its standards for analytical soundness, factual accuracy and policy relevance. It subjects its review and publication process to an annual audit by external experts.

As a registered Canadian charity, the C.D. Howe Institute accepts donations to further its mission from individuals, private and public organizations, and charitable foundations. It accepts no donation that stipulates a predetermined result or otherwise inhibits the independence of its staff and authors. The Institute requires that its authors publicly disclose any actual or potential conflicts of interest of which they are aware. Institute staff members are subject to a strict conflict of interest policy.

C.D. Howe Institute staff and authors provide policy research and commentary on a non-exclusive basis. No Institute publication or statement will endorse any political party, elected official or candidate for elected office. The Institute does not take corporate positions on policy matters.
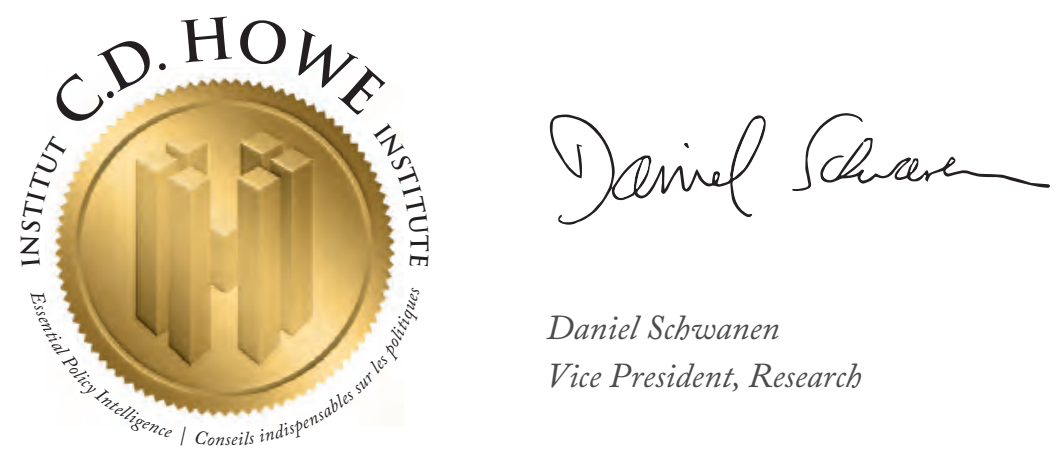

Daniel Schwanen

Vice President, Research 


\section{THE STUDY IN BRIEF}

Many Canadian families with young children struggle with the cost of childcare. The tax system helps alleviate some of that burden. At the federal level, the Child Care Expense Deduction (CCED) allows eligible expenses to be deducted from taxable income. In most cases, expenses must be deducted on the return of the lower-income parent, whose claim cannot exceed two-thirds of income. The CCED is also applied provincially to reduce provincial taxes, except in Quebec where parents benefit from either a provincially subsidized childcare space or from an income-tested refundable tax credit.

Most income tax systems give childcare expenditures special treatment, with different normative motivations in mind. Our approach is more in line with the optimal tax approach in that we evaluate different ways of subsidizing childcare through their contribution to improving efficiency and equity, rather than apply normative rules to determine a single "right" way to treat childcare in the tax system.

A tax system that takes account of empirically demonstrated patterns of behavioural response would seek to encourage work where people's decisions are fairly responsive, improving efficiency and raising more revenue from labour-market earnings. We simulate replacing the CCED with a Quebecstyle refundable tax credit at the federal level, using the same provincial sliding schedule of rates from 75 percent for lower-income earners down to 26 percent for higher earners.

The cost of the refundable credit - applied in all provinces other than Quebec - would be about $\$ 1.2$ billion annually over the current cost of the CCED. However, the fiscal consequences of mothers' employment response would be to reduce the federal fiscal cost by between one-third and one-half in the short term, and by between two-thirds and nine-tenths in the long term, depending on the scenario. Adding the fiscal effects on provinces would yield substantial gains. In the long term, the policy could become socially self-financing as provincial fiscal gains exceed the federal net fiscal cost.

Our analysis suggests that 13 to 19 percent of stay-at-home mothers would enter the labour force as a result of lower net childcare costs. Lower-income families would see a larger reduction in net childcare costs (up to 40 percent on average) than higher-income families, providing relief to the many families of modest income now left out by the existing income test on CCED claims.

Our proposed system would allow diverse childcare providers to offer services, rather than the government-driven system in place in Quebec. Families would retain choice, enlivening the ability of the marketplace to innovate with respect to flexible hours, staffing and facilities. Moreover, if providers were mandated to meet quality markers to be able to issue tax receipts, governments could enforce the quality standards they desire.

Overall, this childcare solution would generate the social benefits of increased labour-force participation, allow for flexible and decentralized childcare choice, and be designed to meet quality standards to foster child development. It would achieve these goals at a potentially small net fiscal cost because of the extra tax revenue resulting from the increased employment.

C.D. Howe Institute Commentary $($ is a periodic analysis of, and commentary on, current public policy issues. Barry Norris and James Fleming edited the manuscript; Yang Zhao prepared it for publication. As with all Institute publications, the views expressed here are those of the authors and do not necessarily reflect the opinions of the Institute's members or Board of Directors. Quotation with appropriate credit is permissible.

To order this publication please contact: the C.D. Howe Institute, 67 Yonge St., Suite 300, Toronto, Ontario M5E 1J8. The full text of this publication is also available on the Institute's website at www.cdhowe.org. 


\section{Childcare expenses present a challenging issue in the budgets of many Canadian families with young children.}

A full-fledged universal program (like Quebec's) combines two separable elements: a price subsidy and the provision of childcare services. A price subsidy affects the budgets of households and their economic incentives to work. The manner of provision, in contrast, determines the quality of the child's learning atmosphere and the cost of providing care. In this Commentary, we examine the price subsidy side of the childcare equation, looking at the impact of changing the tax treatment of childcare expenses on maternal employment and on public finances.

Analysis of Quebec's reduced-fee universal childcare program yields clear and consistent evidence on the effect of subsidized prices on maternal work decisions: in response to the government-subsidized low price, more women are working than would otherwise be the case. ${ }^{1}$ This extra employment, in turn, has an impact on public finances, as the additional household income generates more tax revenue for governments. This phenomenon raises the tantalizing possibility that some of the direct cost of a childcare subsidy might be recouped through higher tax revenues on the extra work that the subsidy induces. ${ }^{2}$

We begin by analyzing the tax treatment of childcare expenses. We then propose switching from the current tax deduction to a generous federal refundable tax credit model - along the lines of Quebec's existing tax credit - that would considerably lower the effective price of childcare for low- to middle-income families, with the net gains from the credit slowly vanishing at higher income levels. Finally, we estimate the likely response of mothers to this employment incentive and how much extra revenue governments, outside Quebec, might expect to garner.

We find that the static cost of a refundable childcare credit - again, outside Quebec - would exceed $\$ 1$ billion. This cost, however, could be cut substantially by the large employment response of mothers: as many as 19 percent of mothers who currently do not work could be induced into the labour force, which would generate hundreds of millions of new tax revenue as well as reduce incometested government benefit payments to families.

For the federal government, which would be instituting the childcare fiscal subsidy, induced tax revenues would reduce the cost of financing the program. For provincial governments, new tax revenues generated by extra maternal work would be a windfall that could be used to fund other priorities.

In the short term, the net cost of the program could be reduced by about three-quarters after accounting for estimated new tax revenues (and lower income-tested government benefit payments)

The authors thank Colin Busby, Philip Merrigan, Munir Sheikh, Tammy Schirle, members of the Fiscal and Tax Competitiveness Council of the C.D. Howe Institute, and anonymous reviewers for comments on an earlier draft. The authors retain responsibility for any errors and the views expressed.

1 See Baker, Gruber, and Milligan (2008); Lefebvre and Merrigan (2008); Lefebvre, Merrigan; and Verstraete (2009); and Milligan (2014). Although fathers are caregivers, too, for practical reasons we focus on maternal work behaviour within the household. This is because most empirical studies focus on the maternal labour supply, and those that have studied both mothers' and fathers' behaviour find that the work response of fathers is relatively small.

2 The fiscal implications of Quebec's childcare program are considered in Baker, Gruber, and Milligan (2005); and Fortin, Godbout, and St-Cerny (2013). 
at the federal and provincial levels. In the long term, assuming that at least some of the program's beneficial impact on maternal employment persists as children enter their school-age years, the program might generate more revenue than it costs - paying for itself through the induced extra employment work and associated tax revenue.

Revamping the tax treatment along the lines we suggest here would emphasize the natural advantages of the market: competition can drive innovation in facilities, flexible hours, staffing and more. This potentially would improve on the more rigid provision of care in the Quebec model. Of course, the quality of care is an important concern, and so we close with a discussion of how the tax treatment of childcare could be enhanced to reinforce quality standards.

\section{WHY SHOULD CHILDCARE EXPENSES GET SPECIAL TAX TREATMENT?}

Most income tax systems give childcare expenditures special income tax treatment, with different possible motivations in mind. Three such motivations are to acknowledge the principle of ability-to-pay, to influence the price of the service, and to affect income distribution.

In the standard "ability-to-pay" framework, an individual's income should be adjusted for various items to arrive at the best possible measure of that person's ability to pay, given the person's particular circumstances. The motivation for the adjustments is to put different people on a comparable basis before the schedule of income tax rates and brackets is applied to their income. ${ }^{3}$ In this way, only the residual consumable value of a person's total income is included in the base for taxation. Childcare expenses are viewed as a cost of earning income, rather than as something that provides consumption value to the household. Just as firms are taxed on their revenue net of expenses, so people should be taxed on their income net of expenses incurred in earning that income. Thus, a household with income of $\$ 50,000$ and no childcare expenses might be considered similar to a household with income of $\$ 55,000$ and $\$ 5,000$ of childcare expenses. Allowing a deduction for childcare expenses in principle allows households to be taxed similarly, whether or not they have childcare expenses.

Another possible motivation for special tax treatment for childcare is to influence, through a subsidy, the price of the service. Such treatment might be appropriate if the expenditure generated positive externalities, meaning that a family's chosen expenditure would be too low if left to the market price alone, which would not account for the spillovers to other families or to society as a whole. Or the subsidy might aim to counteract the negative incentives of other public policies or taxes. Also, from a behavioural economics "nudge" perspective, since some people might not be aware of the benefits or costs of an action, government could use prices to nudge families toward a preferred action.

The case for externalities with respect to childcare does not emerge naturally. One might argue that externalities arise when children interact with classmates from different backgrounds, which helps to equip them for such interactions in Canada's diverse society later in life. But even if true, these interactions might not need to begin at pre-school ages or in the milieu of childcare. The "nudge" argument might hold sway if formal childcare environments were proven to be better for children and their families, and if parents did

3 The 1967 Royal Commission on Taxation (the Carter Commission) provided a framework for the ability-to-pay approach. For childcare expenses, however, the Commission recommended a tax credit at the highest marginal rate, rather than a deduction; see Canada (1967: 3, chap. 7, 19). 
not account for these advantages when making decisions. Of course, this would put much responsibility on the government giving the nudge by assuming it has better information about the children than do their parents.

A third motivation for according special income tax treatment to an expenditure item is to influence the distribution of well-being between different segments of society. If childcare is used more heavily by those with a high standard of well-being, subsidizing its consumption would improve the well-being of the well-off at the expense of others. Deductions from taxable income give higher-value tax reductions to high earners under a progressive rate schedule, which some view as unfairly subsidizing childcare for high earners. This line of thinking was behind the transformation of many deductions into flat-rate tax credits in the 1988 federal income tax reform.

Undoubtedly, each of these motivations drives some part of the discussion on the tax treatment of childcare. One way to tie these concerns together is by applying the optimal tax approach to tax design, in which the subsidizing of any particular activity is evaluated flexibly through its contribution to improving efficiency and equity, rather than applying fixed normative rules of what should be taxed. ${ }^{4}$ Our approach is more in line with the optimal tax approach in that we wish to evaluate the effect of different ways of subsidizing childcare, rather than apply normative rules to determine a single "right" way to tax childcare.

\section{HOW THE CANADIAN INCOME TAX TREATS CHILDCARE EXPENSES}

How does Canada's tax system treat childcare expenses? At the federal level, the Child Care Expense Deduction (CCED) allows eligible childcare expenses for an eligible child to be deducted from taxable income; in most cases, it must be deducted on the return of the lowerincome parent. Moreover, the claim cannot exceed two-thirds of the income of the lower-earning spouse. For children ages 0 to 6 , the current maximum deduction limit is $\$ 8,000$ per year; for those ages 7 to 16 it is $\$ 5,000$ per year. For children of any age eligible for the disability amount, the limit is $\$ 11,000$ per year. These limits have not been explicitly indexed to inflation, but instead have been increased periodically since the limit was first introduced at $\$ 500$ in 1972 .

Quebec administers its income tax separately from the federal government. Until 1993, childcare expenses were deductible, with limits similar to the federal criteria. Starting in 1994, Quebec switched to a refundable credit with a very generous rate that declined for those with higher family income (see Appendix Table A-1). In 2015, the refundable tax credit rate for family income under about $\$ 35,000$ was 75 percent; for family income of about $\$ 152,000$ or more, the rate was 26 percent. Families with children in Quebec's subsidized childcare program are not eligible for the credit. For higher earners, this credit is worth slightly more than the deduction; for middle and lower earners, it is worth substantially more.

As Table 1 shows, ${ }^{5}$ in 2015, 1.2 million Canadian working families, or 39 percent of all such families, claimed the CCED. The proportion rose from 29 percent among those with family income under $\$ 25,000$ to 48 percent of those with family income of $\$ 100,000-\$ 150,000$. In total, about $\$ 5$ billion in childcare expenses was claimed, with an

4 See Banks and Diamond (2010) and Boadway (2014) for a discussion of the modern optimal tax approach to tax design.

5 This analysis and all of the simulations performed throughout this Commentary are based on Statistics Canada's Social Policy Simulation Database and Model (SPSD/M), version 22.0. The assumptions and calculations underlying the simulation results are those of the authors, as is responsibility for the use and interpretation of these data. 


\section{Table 1: Use of the Federal Child Care Expense Deduction (CCED) by Canadian Families, by Family Income, 2015}

\begin{tabular}{|c|c|c|c|c|c|c|}
\hline \multirow{2}{*}{$\begin{array}{c}\text { Family Income } \\
\text { (\$) }\end{array}$} & \multicolumn{2}{|c|}{$\begin{array}{l}\text { Eligible Families* } \\
\text { Claiming the CCED }\end{array}$} & \multirow{2}{*}{$\begin{array}{l}\text { Amount } \\
\text { Claimed } \\
\text { (\$ million) }\end{array}$} & \multirow{2}{*}{$\begin{array}{c}\text { Average } \\
\text { Amount per } \\
\text { Claiming } \\
\text { Family } \\
\text { (\$) }\end{array}$} & \multirow{2}{*}{\begin{tabular}{|} 
Percent of \\
Claiming \\
Families \\
Bounded by \\
Maximum \\
Deduction \\
Limit per Child \\
(percent)
\end{tabular}} & \multirow{2}{*}{$\begin{array}{c}\text { Percent of } \\
\text { Claiming } \\
\text { Families } \\
\text { Bounded by } \\
\text { Income Limit } \\
\text { (2/3 of lower- } \\
\text { income spouse) } \\
\text { (percent) }\end{array}$} \\
\hline & (thousand) & (percent) & & & & \\
\hline Min.-25,000 & 142.6 & 29 & 320.7 & 2,248 & 2 & 59 \\
\hline $25,001-50,000$ & 148.5 & 31 & 429.7 & 2,893 & 5 & 33 \\
\hline $50,001-75,000$ & 180.6 & 37 & 551.4 & 3,053 & 1 & 31 \\
\hline $75,001-100,000$ & 211.2 & 43 & 862.1 & 4,082 & 3 & 22 \\
\hline $100,001-150,000$ & 310.1 & 48 & $1,222.4$ & 3,942 & 7 & 18 \\
\hline 150,001-max. & 244.1 & 44 & $1,546.8$ & 6,338 & 23 & 10 \\
\hline All & $1,237.1$ & 39 & $4,932.9$ & 3,988 & 8 & 26 \\
\hline
\end{tabular}

average value of $\$ 3,988$, or about $\$ 332$ a month. The average claim increased with income, so that those in the highest income group claimed about three times as much on average as those in the lowest income group. As the final two columns of the table show, the maximum dollar limit was binding for about 8 percent of claiming families, ${ }^{6}$ while the proportion constrained by the maximum limit was 23 percent for the highest income group (over $\$ 150,000$ in family income) - the only income group for which the percent constrained reached double digits. In contrast, the income limit was much more important at lower income levels, with 59 percent of those claiming with family income under $\$ 25,000$ bound by the two-thirds-of-income rule. Because of this, a substantial proportion of lower- and middle-income Canadian families were not able to deduct fully their childcare expenses.

6 It is possible that parents know the threshold, and do not include the full expenditure amount if it exceeds the threshold. The main data source for CCE, however, is not administrative income tax data from the Canada Revenue Agency (CRA), but data from Statistics Canada's Survey of Household Spending, so it is less likely that parents would feel constrained by the tax threshold when reporting their incurred CCE for the survey. Comparing the SPSD's distribution of the CCED by total income group and the tables of income statistics published by the CRA shows that the former accounts for around 93 percent of the CRA's estimate of the total amount of the CCED in 2010. 
In sum, about 40 percent of Canadian families with eligible children (younger than 16) claim the CCED, and average amounts claimed are fairly small: less than $\$ 500$ per month for most claimants. Many more families are constrained by the income limit on claims than by the maximum dollar limit. So, many lower-income families cannot take full benefit of the CCED because of the income limit, suggesting there is room for a more generous tax treatment of childcare costs on fairness grounds. At the higher family income level, almost a quarter of families are constrained by the maximum deduction amount per child, suggesting room for improvement under the principle that childcare is a cost of earning income. Below we suggest replacing the CCED for a refundable tax credit which, in addition to yielding benefits on equity grounds, would also deliver substantial economic gains.

\section{REFORMING THE TAX TREATMENT OF CHILDCARE EXPENSES}

A tax system that takes account of empirically demonstrated patterns of behavioural response would seek to encourage work where people's decisions are fairly elastic. This would improve efficiency and raise more revenue from labourmarket earnings - which might minimize the need to raise taxes elsewhere. To see how much impact the different tax treatment of childcare could make, we can look at Quebec's refundable tax credit. The province has two distinct and exclusive subsidy programs for childcare, and parents cannot claim both. The first is the well-known subsidy to eligible childcare providers, which then charge parents a subsidized lower daily rate. ${ }^{7}$ The second is a refundable tax credit for the cost of private childcare, which parents with children in subsidized childcare cannot claim. ${ }^{8}$

We simulate the implications of replacing the federal CCED with a Quebec-style refundable tax credit, at the federal level, using the same sliding schedule of rates from 75 percent for lower-income earners down to 26 percent for higher earners (see Appendix Table A-1). We simulate two scenarios with respect to provincial policy responses. In scenario A, provincial deductions for childcare costs remain in place, even with the elimination of the deduction at the federal level. In scenario B, provincial childcare cost deductions are eliminated in line with the federal change. We aim to assess the static fiscal cost of such a move, as well as the dynamic effect through induced labour supply. This allows us to see how much of the extra cost could be recovered through tax revenue gained from the extra labour supply induced by the policy change.

To simulate the impact of the two scenarios, we use Statistics Canada's SPSD/M, a large, sophisticated and widely used tax simulation database of Canadian taxfilers. It enables us to compute not only the changes in taxes paid by households, but also the changes in income-tested benefit payments (such as child benefits) as a result of eliminating childcare deductions or inducing extra work income. The SPSD/M delivers us the static estimates - that is, not accounting for the response of labour supply to the new incentives. We then augment the static analysis by drawing on evidence of the response of maternal labour supply to changes in work incentives. After reviewing recent evidence, we took the 0.24 elasticity estimate from Baker, Gruber, and Milligan (2008) as the

7 The rate is a basic parental contribution of $\$ 7.75$ per day and an additional contribution increasing with family income up to a maximum daily rate of $\$ 21.20$ (both the basic and additional rates are indexed to inflation).

8 As of March 31, 2016, of all Quebec children in government-registered childcare, about 20 percent benefited from the refundable credit and 80 percent from a subsidized childcare space (Quebec 2017). This does not include children in a nonregistered daycare service, such as a private babysitter, whose parents could also apply for the credit. 
central case. ${ }^{9}$ The elasticity measures the percentage change in the probability of working for a given percentage change in the cost of childcare. So, a 10 percent change in the cost of childcare (due to a change in the subsidy rate) would yield a 2.4 percent change in the probability of working. We focus on the extensive margin, where the work decision is whether or not to work at all, rather than on the intensive margin, where the decision is how many hours to work. Since evidence suggests that most of the shifting in response to childcare price changes are on the extensive margin, our modeling accounts only for the extensive margin shift from not working to working.

For our response simulations, we focus on a sample of mothers of children between the ages of zero and six. Of course, there are important differences even within this pre-school range as children move from infancy to becoming toddlers, so our modelling effectively takes an average of the responses of these children. In addition, we extend the analysis to 7-to-15-year-olds, to see what might happen in the long run: if work patterns for women with children ages zero to six become persistent, childcare could have an impact beyond the preschool years. ${ }^{10}$ This turns out to be an important consideration for net fiscal costs because childcare costs of school-age children are low, while any boost to the labour supply would provide consistent tax revenue.

\section{RESULTS}

The results of our simulations appear in Table 2. The first row reports the static fiscal cost of implementing a Quebec-style refundable credit in all provinces except Quebec. The current CCED has a low value for low earners and a high value for high earners, while a refundable tax credit would have the opposite pattern. In almost all cases, however, the value of the credit would exceed the value of the deduction. The total static net cost estimate across all income groups is $\$ 1.188$ billion.

\section{Short-term Labour Supply Effects}

Short-term labour supply consequences of our scenarios are shown in the first and third columns of Table 2. In the second row, we estimate the change in the number of mothers who work, a function of the elasticity and change of the net cost of childcare. To do this, we simulate the additional tax savings that a stay-at-home mother would obtain from the new credit if she earned the average employment income of current working mothers of children ages $0-6$ and if she paid average childcare expenses incurred by average working mothers. Because the new credit would have a high rate for low-income families and a low rate for high-income families, the change in the net cost of childcare would be high at low-income levels and low at high-income levels. The reduction in net childcare costs is also lower under scenario $\mathrm{B}$ because mothers would lose the provincial component of the CCED (see Appendix Table A-2). In the short term, 69,494 stay-at-home mothers (19 percent of them) enter the workforce under scenario $A$, and 47,160 mothers (13 percent) do so under scenario $B$. The number of new mothers working is higher under scenario A because they would experience the

9 Estimates for Canada of the extensive margin elasticity include -0.16 (Michalopoulos and Robins 2000); -0.24 (Baker, Gruber, and Milligan 2015); -0.25 to -0.34 (Lefebvre and Merrigan 2008); -0.38 (Powell 1997); and -0.39 (Cleveland, Gunderson, and Hyatt 1996). See Del Boca (2015) for a recent international review.

10 Milligan (2014) finds that cohorts of mothers in Quebec who had young children in the province's childcare program worked more even when their children were ages 6 to 12. Similar findings appear in Lefebvre, Merrigan, and Verstraete (2009). 


\begin{tabular}{|c|c|c|c|c|}
\hline \multirow[t]{2}{*}{ Change } & \multicolumn{2}{|c|}{$\begin{array}{c}\text { Scenario A: Provincial } \\
\text { Childcare Expense Deduction } \\
\text { Kept in Place }\end{array}$} & \multicolumn{2}{|c|}{$\begin{array}{c}\text { Scenario B: Provincial } \\
\text { Childcare Expense Deduction } \\
\text { Eliminated }\end{array}$} \\
\hline & Short Term & Long Term & Short Term & Long Term \\
\hline Static net federal fiscal cost (\$ million) & 1,188 & 1,188 & 1,188 & 1,188 \\
\hline Mothers entering workforce (number) & 69,494 & 126,691 & 47,160 & 84,994 \\
\hline New employment income (\$ million) & 2,616 & 4,768 & 1,775 & 3,199 \\
\hline New childcare expenses to support employment (\$ million) & 448 & 561 & 312 & 397 \\
\hline New benefits paid out (\$ million) & 234 & 293 & 171 & 216 \\
\hline Change in federal taxes (\$ million) & 576 & 1,027 & 417 & 742 \\
\hline Change in federal income-tested benefits (\$ million) & -205 & -367 & -124 & -214 \\
\hline New net federal fiscal cost (\$ million) & 641 & 87 & 818 & 447 \\
\hline Provincial costs (\$ million) & -303 & -556 & -524 & -696 \\
\hline Consolidated federal-provincial net fiscal cost (\$ million) & 337 & -468 & 294 & -249 \\
\hline
\end{tabular}

highest change in the net cost of childcare - which drives the probability of entering the workforce.

The next several rows of Table 2 work through the income and fiscal consequences of more women joining the workforce. Those who work more earn more employment income (income rises by $\$ 1,775$ million to $\$ 2,616$ million), pay more childcare expenses (which increase by $\$ 312$ million to $\$ 448$ million), which in turn generates more refundable childcare tax credits ( $\$ 171$ million to $\$ 234$ million). The extra employment income generates between $\$ 417$ million and $\$ 576$ million in new tax revenue, and lowers total income-tested federal benefits paid out by $\$ 124$ million to $\$ 205$ million, depending on the scenario. This adds up to a net increase in federal tax revenue of between $\$ 293$ million and
$\$ 371$ million. When netted against the $\$ 1,188$ million static cost, this leaves a federal cost including labour supply effects - of \$641 million under scenario A (a 46 percent reduction) and $\$ 818$ million under scenario $B$ (a 31 percent reduction).

The second-to-last row of Table 2 presents the windfall to provincial treasuries from the labour supply boost. In addition, under scenario $\mathrm{B}$, provincial tax revenues gain from the complete elimination of the CCED. Provincial gains range from $\$ 303$ million under scenario $A$ to $\$ 524$ million under scenario B. Subtracting provincial fiscal gains from the federal fiscal cost gives the total consolidated federal-provincial government net cost of the initiative, which, in the short term, is $\$ 337$ million under scenario A and \$294 million under 
scenario B. The labour supply boost therefore reduces the total short-term consolidated government cost of the initiative by about three-quarters.

\section{Long-term Labour Supply Effects}

The second and fourth columns of Table 2 examine potential long-run labour supply effects of the two scenarios. For this case, we assume that women with children ages 7 to 15 increase their labour supply by the same proportion as women with children ages 0 to 6 in each income group. This would occur if mothers' work patterns set during their children's younger ages persist into their school ages - even as the children are no longer in childcare - as evidence from the Quebec childcare program suggests (Lefebvre, Merrigan, and Verstraete 2009; Milligan 2014). We estimate that, in the long term, 15 to 22 percent of stay-at-home mothers move to employment, depending on the scenario. Going through the same steps as above for the short-term effects leaves a net federal longterm annual fiscal cost of $\$ 87$ million in scenario A (a 93 percent reduction over the static fiscal cost) and $\$ 447$ million in scenario B (a 62 percent reduction). Interestingly, because the average cost of childcare is sensibly less for older children, the annual refundable credit payouts do not show a major increase as we move towards longer time horizons, while governments still get the full tax revenue boost of mothers' increased labour supply in the long term. Therefore, even if we assume a lesser beneficial long-term impact on mothers' employment, its positive effect on net government revenues is still substantial.

The fiscal windfalls to provincial governments are larger than the federal net fiscal costs in both longterm scenarios. On a consolidated federal-provincial government basis, the policy change leaves a net fiscal dividend of $\$ 468$ million in scenario $A$ and $\$ 249$ million in scenario B. ${ }^{11}$

\section{OVERALL BENEFITS AND WAYS TO BOOST CHILDCARE QUALITY}

Our analysis suggests that, in the short term, 13 percent of stay-at-home mothers would enter the labour force if provinces discontinued their childcare expense deduction, following the federal lead, and 19 percent would do so if provinces continued to offer the deduction even if the federal counterpart were abolished. Although there might be concern that labour demand might not rise to meet this new supply, the example of Quebec makes clear that the labour market can adjust to accommodate these extra workers.

The static cost of the refundable credit would be $\$ 1,188$ million annually over the current cost of the CCED. However, the fiscal consequences of incremental mothers' employment income and childcare expenses would be to reduce the static federal fiscal cost by between one-third to one-half in the short term, and by between two-thirds and nine-tenths in the long term, depending on the scenario. Adding the fiscal effects on provincial governments would yield substantial gains. In the

11 These results are sensitive to the estimate of the elasticity of the maternal response. We use 0.24 as our central elasticity estimate, based on Baker, Gruber, and Milligan (2005). Using a lower bound elasticity of 0.16 (as in Michalopoulos and Robins 2000), the long-term federal net fiscal cost under scenario A increases to $\$ 454$ million, and the federal-provincial long-term fiscal dividend becomes a cost of $\$ 84$ million. Using a higher elasticity estimate of 0.38 (as in Powell 1997) transforms the long-term federal net fiscal cost under scenario $A$ to a federal dividend of $\$ 555$ million, and increases the federal-provincial dividend to $\$ 1,434$ million. 
short term, the net static cost of the policy change on a consolidated government basis would be reduced by more than half. In the long term, the policy could become self-financing as provincial fiscal gains exceed the federal net fiscal cost.

In addition, due to the income-tested structure of the simulated refundable credit, lower-income families would see a larger reduction in net childcare costs (up to 40 percent on average, depending on the scenario) than higher-income families (see Appendix Table A-2). So not only would this policy make sense from the point of view of economic effectiveness; on the distributional fairness front, it would also provide generous benefits to those currently left out of the deduction scheme because they do not earn enough to benefit fully.

Although the Quebec program has not yielded strong results on child development, ${ }^{12}$ it has been a clear success on the labour supply front. Our simulation results suggest an intriguing possibility: what would happen if the price subsidy were separated from the provision of childcare by offering a tax-based incentive such as the refundable tax credit studied here, but diverse providers, rather than the government-driven system in place in Quebec, were allowed to offer childcare services?

Compared to the more centralized and rigid Quebec model, the potential advantages of decentralizing the provision of childcare would be the natural and celebrated advantages of consumer markets: choice and innovation in staffing, different facility types and flexible hours and modes of care. On the other hand, if parents are not wellinformed, the adverse shortcomings of consumer markets could also arise. Some research suggests that parents systematically undervalue quality - that is, they are unwilling to pay more for care of higher quality $^{13}$ - perhaps due to a lack of information about quality or an inability to assess the available quality signals.

The existing CCED is already decentralized in that parents use the implicit subsidy of the CCED to purchase care from the provider of their choice. So replacing the CCED with a refundable credit would not change how the tax system addresses the quality of care. With the increased subsidy of a refundable credit, however, the opportunity would arise to improve on the quality signals the market provides under the status quo. The financial incentives of the refundable credit could pull some parents out of more informal care into more formal care modes. That is, the attractiveness of the large refundable credit could shift families into care types typically considered of a higher quality that families could not have afforded in the absence of the credit. The refundable credit would be much more generous for most families, especially those with low income, so the impact of the choice of mode of care might be most relevant for them. The credit could be refined further to require providers meet specified quality markers in order to be able to issue tax receipts. These quality standards could be set and assessed by local or provincial governments as part of their existing regulatory regime. Of course, this might entail increased administrative costs, but the advantage of keying the subsidy to quality standards is that desired quality levels could be met while leaving the provision of the services decentralized and flexible.

Overall, this childcare solution would generate the social benefits of increased labour-force participation, allow for flexible and decentralized childcare choice and be designed to meet quality standards to foster child development. It would

12 See Baker, Gruber, and Milligan (2008, 2015); and Kottelenberg and Lehrer (2013).

13 See, for example, Blau and Hagy (1998) or the evidence reviewed in Blau (2001); the idea of keying the subsidy to meeting quality standards comes from the latter. 
achieve these goals at potentially small net cost because of the extra tax revenue resulting from the increased employment.

\section{CONCLUSION}

Evaluating the effect of a potential tax subsidy on maternal work and government finances is a more practical and flexible approach to tax policy than applying normative rules to determine a single "right" tax treatment of childcare expenses. In modelling a refundable tax credit for childcare expenses along the lines of the provincial credit offered in Quebec but applied federally to the rest of Canada, we find that the subsidy, in the long term, could generate more government revenue than it costs - that it could pay for itself through the induced extra work and associated tax revenue.

In addition to increased revenue, three clear advantages of a refundable tax credit emerge from our analysis. First, such a credit system would improve fairness by providing childcare cost relief to the many families of modest income now left out by the existing income test on CCED claims. Second, families would retain choice under our model, which would enliven the ability of the marketplace to innovate with respect to flexible hours, staffing and facilities. Finally, a generous refundable credit could improve the environment for quality childcare by providing an incentive to move from informal to more formal care. Moreover, if the provider were mandated to meet quality markers to be able to issue tax receipts, governments could enforce the quality standards they desire. In light of these advantages, the federal government should consider changing its tax treatment of childcare expenses from the current tax deduction to a refundable tax subsidy. 


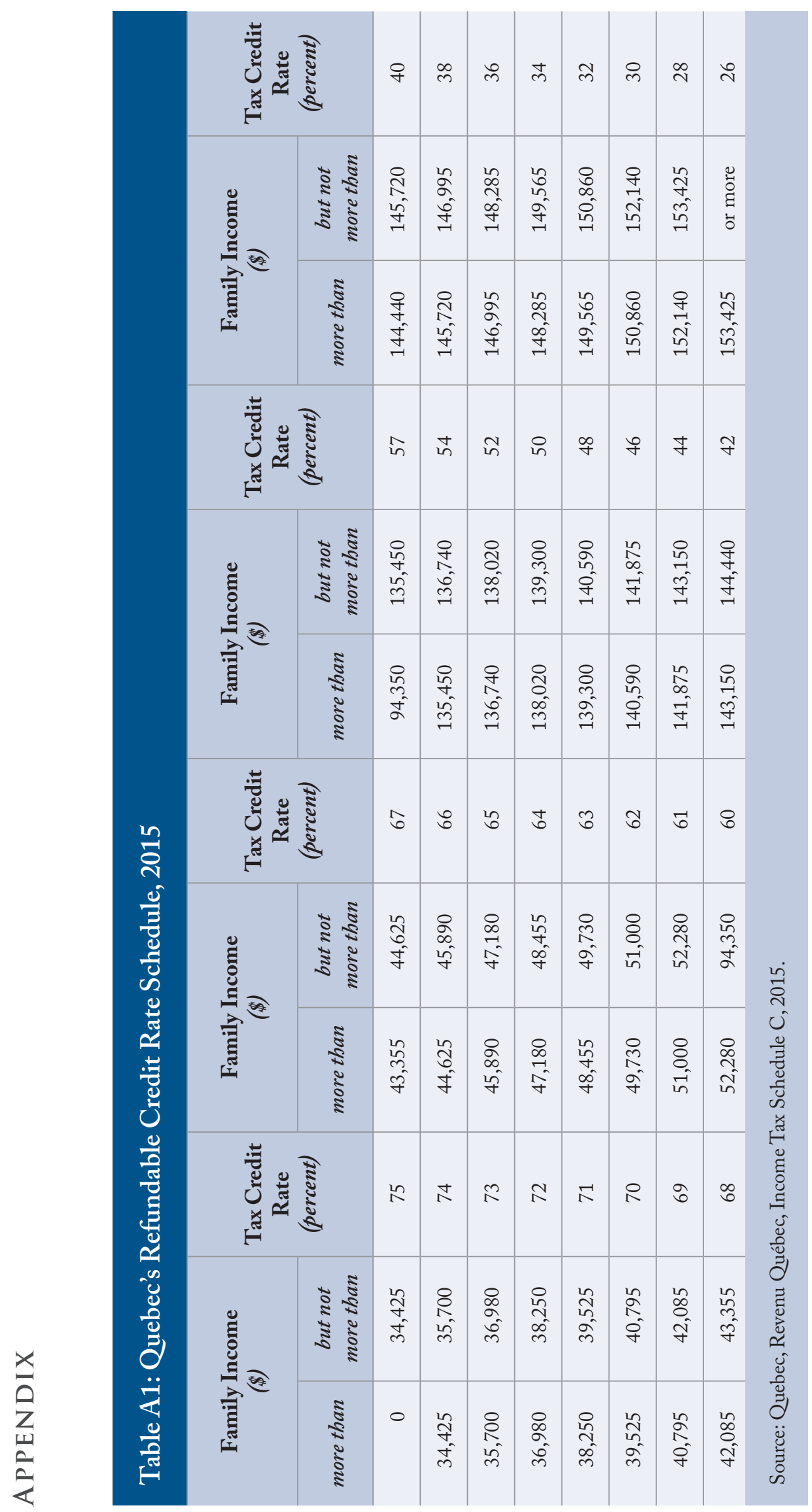




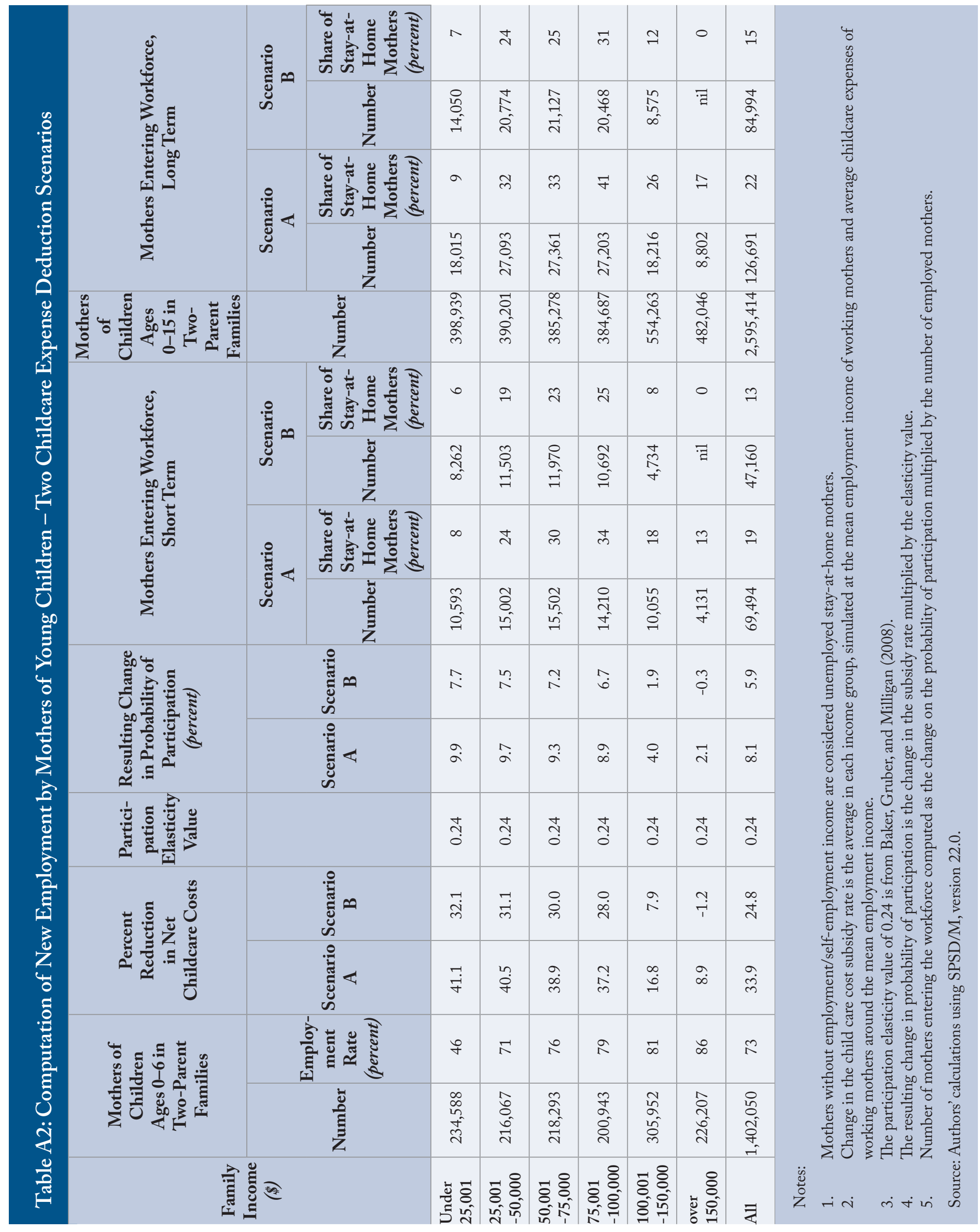




\section{REFERENCES}

Baker, Michael, Jonathan Gruber, and Kevin Milligan. 2005. "Universal Childcare, Maternal Labor Supply, and Family Wellbeing.” NBER Working Paper 11832. Cambridge, MA: National Bureau of Economic Research.

___ 2008. "Universal Childcare, Maternal Labor Supply, and Family Wellbeing.” Journal of Political Economy 116 (4): 709-45.

__ 2015. "Non-cognitive Deficits and Young Adult Outcomes: The Long-Run Impacts of a Universal Child Care Program.” NBER Working Paper 21571. Cambridge, MA: National Bureau of Economic Research.

Banks, James, and Peter Diamond. 2010. "The Base for Direct Taxation.” In Dimensions of Tax Design, edited by James Mirrlees, Timothy Besley, Richard Blundell, Stephen Bond, Robert Chote, Malcolm Gammie, Paul Johnson, et al., 548-648. Oxford: Oxford University Press.

Blau, David M. 2001. The Child Care Problem: An Economic Analysis. New York: Russell Sage Foundation.

Blau, David M., and Alison P. Hagy. 1998. "The Demand for Quality in Child Care." Journal of Political Economy 106 (1): 104-46.

Boadway, Robin. 2014. "Piecemeal Tax Reform Ideas for Canada: Lessons from Principles and Practice." Canadian Tax Journal 62 (4): 1029-84.

Canada. Royal Commission on Taxation \& Carter, Kenneth Le M. 1967. Report of the Royal Commission on Taxation. Queen's Printer. Ottawa.

Cleveland, Gordon, Morley Gunderson, and Douglas Hyatt. 1996. "Child Care Costs and the Employment Decision of Women: Canadian Evidence." Canadian Journal of Economics 29 (1): 132-51.

Del Boca, Daniela. 2015. "Child Care Arrangements and Labor Supply.” IDB Working Paper Series IDB-WP-569. Washington, DC: Inter-American Development Bank.
Fortin, Pierre, Luc Godbout, and Suzie St-Cerny. 2013. "L'impact des services de garde à contribution réduite du Québec sur le taux d'activité féminin, le revenu intérieur et les budgets gouvernementaux." Interventions économiques 47: 1-28.

Kottelenberg, M.J., and S.F. Lehrer. 2013. "New Evidence on the Impacts of Access to and Attending Universal Child-Care in Canada." Canadian Public Policy 39 (2): 263-86.

Lefebvre, P., and P. Merrigan. 2008. "Child-Care Policy and the Labor Supply of Mothers with Young Children: A Natural Experiment from Canada." Journal of Labor Economics 26 (3): 519-48.

Lefebvre, P., P. Merrigan, and M. Verstraete. 2009. "Dynamic Labour Supply Effects of Childcare Subsidies: Evidence from a Canadian Natural Experiment on Low-fee Universal Child Care." Labour Economics 16 (5): 490-502.

Michalopoulos, C., and P.K. Robins. 2000. "Employment and Child-Care Choices in Canada and the United States." Canadian Journal of Economics 33 (2): 435-70.

Milligan, Kevin. 2014. “The Road to Egalitaria: Sex Differences in Employment for Parents of Young Children." CESifo Economic Studies 60 (2): 257-79.

Powell, L. 1997. “The Impact of Child Care Costs on Labour Supply of Married Mothers: Evidence from Canada." Canadian Journal Economics 30 (3): 577-94.

Quebec. 2017. "Création de places en services de garde.” Quebec City: Ministère de la famille. Available at online at https://www.mfa.gouv.qc.ca/fr/servicesde-garde/portrait/places/Pages/index.aspx, accessed March 30, 2017. 
NOTES: 
NOTES: 


\section{ReCEnt C.D. Howe Institute Publications}

May 2017

May 2017

May 2017

May 2017

avril 2017

April 2017

April 2017

April 2017

April 2017

March 2017

March 2017

March 2017

mars 2017
Blomqvist, Åke, and Colin Busby. The Paradox of Productivity, Technology, and Innovation in Canadian Healthcare. C.D. Howe Institute Commentary 480.

Matthews, Lesley. How to Restore Public Trust and Credibility at the National Energy Board. C.D. Howe Institute Commentary 479.

Church, Jeffrey. Defining the Public Interest in Regulatory Decisions: The Case for Economic Efficiency. C.D. Howe Institute Commentary 478.

Robson, William B.P., and Alexandre Laurin. "Premium Compensation: The Ballooning Cost of Federal Government Employees.” C.D. Howe Institute E-Brief.

Busby, Colin, Aaron Jacobs, et Ramya Muthukumaran. Besoin d'un rappel? Comment améliorer la couverture vaccinale des enfants au Canada. Institut C.D. Howe commentaire 477.

Busby, Colin, Aaron Jacobs, and Ramya Muthukumaran. In Need of a Booster: How to Improve Childhood Vaccination Coverage in Canada. C.D. Howe Institute Commentary 477.

Robson, William B.P., and Colin Busby. Numbers You can Trust? The Fiscal Accountability of Canada's Senior Governments, 2017. C.D. Howe Institute Commentary 476.

Robins, Steven. "Surge Capacity: Selling City-owned Electricity Distributors to Meet Broader Municipal Infrastructure Needs.” C.D. Howe Institute E-Brief.

Brown, Robert L., and Shantel Aris. Greener Pastures: Resetting the Age of Eligibility for Social Security Based on Actuarial Science. C.D. Howe Institute Commentary 475.

Schwanen, Daniel, and Aaron Jacobs. Patents, Copyright and Competition: Assessing the Impact of Trade Deals on Canada. C.D. Howe Institute Commentary 474.

Dachis, Benjamin. New and Improved: How Institutional Investment in Public Infrastructure can Benefit Taxpayers and Consumers. C.D. Howe Institute Commentary 473.

Robson, William B.P., Aaron Jacobs, and Benjamin Dachis. "Equipment Failure: Feeble Business Investment Costs Canadians their Competitive Edge.” C.D. Howe Institute E-Brief.

Oschinski, Matthias et Rosalie Wyonch. Le choc du futur? Les répercussions de l'automatisation sur le marché du travail au Canada. Institut C.D. Howe commentaire 472.

\section{SUPPORT THE INSTITUTE}

For more information on supporting the C.D. Howe Institute's vital policy work, through charitable giving or membership, please go to www.cdhowe.org or call 416-865-1904. Learn more about the Institute's activities and how to make a donation at the same time. You will receive a tax receipt for your gift.

\section{A REPUTATION FOR INDEPENDENT, NONPARTISAN RESEARCH}

The C.D. Howe Institute's reputation for independent, reasoned and relevant public policy research of the highest quality is its chief asset, and underpins the credibility and effectiveness of its work. Independence and nonpartisanship are core Institute values that inform its approach to research, guide the actions of its professional staff and limit the types of financial contributions that the Institute will accept.

For our full Independence and Nonpartisanship Policy go to www.cdhowe.org. 

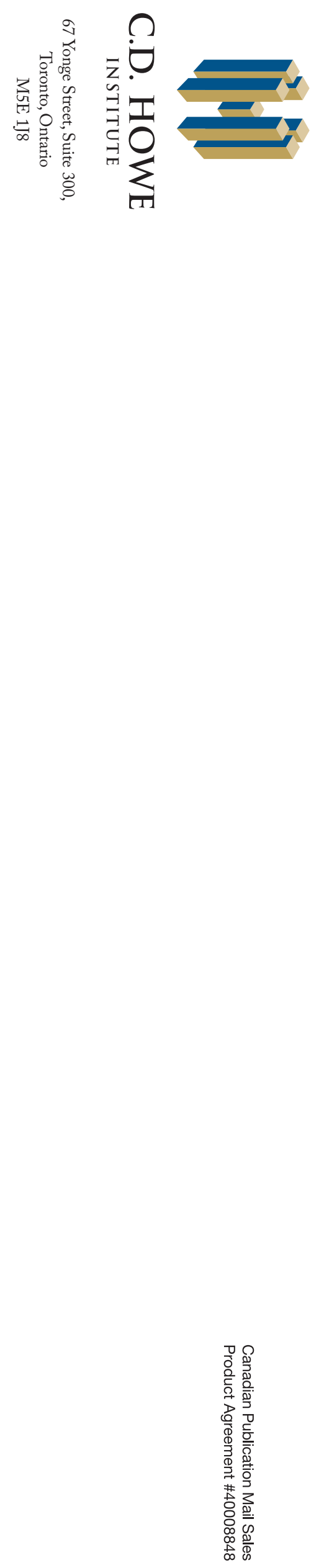